\title{
THE COMPANY ACCOUNTING EVALUATION - PRELIMINARY PHASE OF THE PROPER ANALYSIS OF FINANCIAL STATEMENTS
}

\author{
Păcurari Doina, Assistant \\ UNIVERSITY OF BACAU \\ Muntean Mircea, Associate Professor, PhD \\ UNIVERSITY OF BACAU
}

\begin{abstract}
:
The problem that the accounting information do not always reflect the economic reality may affect the analysis and forecast based on financial statements. This is due both to the accrual accounting limitations and to the fact that this type of accounting allows the result management. In spite of some disadvantages, the accrual accounting is considered superior to cash accounting in measuring the performances and determining financial position as well as in the predicting of future cash flow. In order to limit the negative effects on the results of analysis and forecast based on financial statements, the analists should evaluate the enterprise accounting and if necessary adjust the financial statements so they reflect the economic reality.
\end{abstract}

The enterprise's accounting evaluation represents an important pre-condition in effective financial analysis. This aspect is due to the fact that the quality of the results of financial analysis and of the influences established through it depends on the quality of the accounting correspondent information, row material of analysis.

It actually deals with a process of evaluation of the measure in which the reported accounting data reflects the economic reality. This analysis supposes a number of different tasks, such as: the risks evaluation in the accounting of enterprise and the quality of the accounting results, the estimation of the result's information power, as well the realization of the necessary adjustments on the financial situations both for a better reflection on the economic reality and in order to serve better the financial analysis.

The accrual accounting offers important clues regarding the enterprise's performance and financial situation, but its imperfections may distortion the economic contents of the financial reports. These deviations of accounting information from the correspondent economic reality, named accounting distortions have on their basis factors such as: the accrual accounting standards, estimation errors, the balance between the relevance and the credibility of information and attitude in accrual accounting application.

$>$ The accounting standards may represent the cause of some accounting distortions from two main reasons:

- the former refers to the fact that the accounting standards are the reflections of a political process, where different groups of users make lobby in order to protect their own interests, and in this process the standards flow sometimes in demanding the most relevant information;

- the latter is pointing some accounting methods and principles that standards base upon and that may affect the quality of the reported information. One example for this case is represented by the historical cost principle that may reduce the relevance of the balance sheet by the fact that does not reflect the assets and the liabilities at the current market values. Another principle, the one of conservatism, leads to a pessimist side in preparing the financial statements, the accountants registering in most cases the depreciations afferent to assets but unregistering the extra-value concerning the controlled assets. This prudence, even though is benefic in analysis for crediting, may constitute a problem in analyzing the equity. Another example refers to the stocks evaluation methods. This methods influence both the balance-sheet's and the profit and loss account "reality", but on a different 
manner. The FIFO method, for instance, ensures the presentation in the balance-sheet of the unsold stocks to a cost more close to the current cost, but it does not allow a good reflection of sales and of commercial margin in the profit and loss account, such the LIFO method does.

$>$ Estimations errors. In accrual accounting certain predictions and estimations concerning the future cash flows are imposed. These predictions and estimations realized by the accounting information producers, that know better the enterprise's situation, may increase the utility of the reported data. In the same time, the estimations may cause errors that will influence negatively the relevance in the accounting information. It is the case of both provisions and adjustments for assets' depreciation.

$>$ The balance between the information's relevance and credibility. A bigger stress put upon the information credibility prevents many times the recognition in financial statements of some sure events and transactions before the corresponding cash to be estimated reasonably. An example for this issue is constituted by contingent expenses. Another example of deformation is represented by the credibility stressing is the accounting of the research and development expenses. Even though it represents an investment, the present accounting standards demand their registering as an expense because the payment made for this are less "secure" than those for known investments expenses, such as plants and equipments.

$>$ Attitude in applying the accrual accounting. It is probably, the most problematic among the consequences of the accounting appliance. The use of policies and specific methods of this type of accounting may allow managers to manipulate the accounting data and to use their own experience in order to obtain accounting information as much useful for them as possible. The indicators most appointed by managers with the purpose of manipulation are those of profitability, especially the accounting result. The result management may appear form reasons such as: the increase of managers' income in the case of obtaining superior performances, the avoidance of obligation contracts, the reduction of profit taxes, the favoring of analysts' forecasts and the influencing of shares' prices etc. It may be realized either through the change of accounting methods, or by means of the changing of estimations and accounting policies. The accounting politics application must be relied on the professional judgement. However, sometimes the professional judgement leads to the discloused result and financial position deformation and we can talk in this situation about an aggressive application of the accounting politics not about a result management. Unfortunately, if the information producer still pick out certain politics for reflect a specious image of the enterprise's financial performances instead of using the flexibility in accounting options choosing for reflect a faithful image, we can talk about a creative accounting. No matter the reason for which it is used, the result management affects the financial information credibility.

In spite of all this mentioned disadvantages, the accrual accounting is considered superior to cash accounting under the measure of performances and financial position as well as in the predicting of future cash flows. In order to limit the effects of such disadvantages upon the financial statements it is recommended the following of the next two phases:

\section{1) The result's quality evaluation}

Taking into consideration the result management's implication upon the analysis, the following aspects are checked in order to establish whether the enterprise's result was affected or not by certain manipulation techniques:

- the existence of reasons for result's manipulation;

- the managers' reputation (the last financial statements, the audit reports, auditor's change during time are taken under consideration etc.);

- consistency in applying the accounting policies and methods;

- the opportunities for application of result manipulation's technique (certain fields of activity suppose more situations where the professional reasoning and estimation are 
imposed, and as consequence, may favor the wiling change of information from financial statements).

\section{2) The adjusting of financial statements}

The second phase of the enterprise's accounting analysis points out the filling in or the correction, if needed, of financial statements on the basis of supplementary information that can be usually found in the explicative notes. These adjustments include:

- the operational leasing capitalization, with the correcting of both balance-sheet and the profit and loss account;

- the recognition of stock-options expenses at the result determination;

- the correcting of registered adjustments and provisions;

- the recognition as liabilities in the balance-sheet of retirement funds and other advantages post-employment;

- the replacing form the balance-sheet of passives and actives concerning the delayed profit tax.

The financial statements therefore adjusted allow a better analysis through flows and facilitates the financial forecast.

The evaluation of the enterprise's accounting system, for financial analysis and diagnosis, should also take under consideration the accounting settlements that it applies upon. It was noticed that in the countries where the accounting settlements are very strict, the forecast based on financial analysis results are more precise. If a financial statements drawing based on strict reglementations facilitates the comparative analysis the situation may be different if we refer to the prospective analysis. This later type of analysis depends in a more large measure on the presentation in the real values of the balance-sheet and the profit and loss account elements. Actually, the adjustement of the financial statements in this preliminary phase to financial analysis aims just at the correction of the balance-sheet and of the profit and loss account, the main components influenced by the accrual accounting application.

The external users' information referring to accounting methods is very useful in interpretation and valorization of financial analysis results. This is reason for the increasing of informational role of the explanatory notes in last years. Moreover, the voluntary information supply regarding the previous activity and the business prospect represents a solution for more and more companies, especially for listed companies. The voluntary information supply addresses mainly to the investors and analists, supporting them in forecast and investment decision foundation.

The enterprise's accounting evaluation phase accomplishment, having as result the removing of the effects of the accounting distorsions on the financial statements, allows the analists to use more accuratelly the financial figures and ratio and to achieve the financial previsions demanded by the users.

\section{References:}

[1] Bae, K.H., Tan, H., Welker, M., International GAAP Differences: The Impact on Foreign Analysts, The Accounting Review, Vol.83, No.3/2008

[2] Helfert, E.A., Tehnici de analiză financiară: ghid pentru crearea valorii, Ed.BMT Publishing House, Bucureşti 2006;

[3] Petrescu, S., Analiză şi diagnostic financiar-contabil: ghid teoretico-aplicativ, Ed.CECCAR, Bucureşti 2008;

[4] Vâlceanu, Gh., Robu, V., Georgescu, N., Analiză economico-financiară, Ed.Economică, Bucureşti 2004;

[5] Wild, J.J., Subramanyam, K.R., Halsey, R.F., Financial Statement Analysis, $9^{\text {th }}$ edition, McGrow Hill, N.Y.2007. 